\title{
TVET as an important factor in country's economic development
}

\author{
Margarita Pavlova \\ From Practical Social and Industrial Research (PSIR) Symposium 2014 \\ Wanchai, Hong Kong. 5 December 2014
}

Education and training for productive employment is vital for economic and social development in Asia and the Pacific. Technical and Vocational Education and Training (TVET) is viewed as a tool for productivity enhancement and poverty reduction in the region. As there is a strong correlation between the proportion of TVET students at the post-secondary level (tertiary, non-degree, ISCED 5b) and per capita income [1] many countries have taken steps to strengthen policy guidance and regulatory frameworks for technical and vocational education and training and to improve partnerships with private sector and employers. However, there is a difference between developed and less developed countries in terms of their first priorities regarding TVET. The first group of countries emphasize quality improvement, monitoring and evaluation of TVET, the availability of national development plans, but the second group of countries focus on the cost of enrolment and implementation of TVET [2]. Although skilled human resources are the primary asset of many countries in the region, an inadequately educated workforce is still among the most problematic factors for doing business in many countries in Asia and the Pacific [3].

This presentation brings together a number of areas of strategic development for Hong Kong stated in the 2014 Chief Executive's Policy Address; namely economic development, innovation and technology industries, vocational education and environmental protection. High performance in increasingly competitive global economies combined with the need to address global challenges posed by climate change and carbon emissions, environmental degradation and pollution, health, and poverty, require successful countries to adapt innovation-driven strategies for growth that should be supported by TVET. The

Correspondence: mpavlova@ied.edu.hk

UNESCO-UNEVOC Centre (Hong Kong), Hong Kong Institute of Education, Hong Kong

SpringerOpen $^{\odot}$

(C) 2014 Pavlova; licensee Springer. This is an Open Access article distributed under the terms of the Creative Commons Attribution License (http://creativecommons.org/licenses/by/4.0), which permits unrestricted use, distribution, and reproduction in any medium, provided the original work is properly credited. importance of transitions towards greener economies has been recognized globally, by both regions and separate countries (e.g. The Europe 2020 Strategy [4]; The Central People's Government of the People's Republic of China, 2011 [5]). Economic and Social Survey of Asia and the Pacific (ESCAP) [6] concludes that government policies that are directed towards strengthening social and environmental pillars of sustainable development could serve as "the solution to improving the quality of growth in the region" ([6] p.62). For Asia and the Pacific, the development of the "green economy" that recognizes the "important interlinkages between the environmental resource base, economic systems and social development" [7, p.50] could lead to investment and capacity development in such areas as renewable energy resources, green manufacturing sectors, urbanization, food security, sustainable agricultural practices and biodiversity. China, for example, identified the aim of developing a circular economy as one direction of their current Fifth year plan [5], the economy, where 'reduce, reuse and recycle' at every stage of production and consumption are promoted. The Government of Hong Kong SAR has invested strategically in innovation and technology as drivers for economic growth and competitiveness as due to environmental challenges, "faster and broader innovation of new technology is critical for achieving a sustainable future, [particularly], "the development of green industries" [8].

Economic changes caused by green restructuring should be supported by human resource development that results in significant impact on skills. This presentation examines how TVET can contribute to green economic restructuring in the region through developing effective approaches towards formulation of green skills (technical skills, knowledge, values and attitudes necessary for worker for the transition to an economy with a reduced negative impact on the environment) [9]. It also evaluates greening of TVET in several Asian 
countries and argues that green innovation supported by governments could play an important role in transition towards a greener economy that in turn results in inclusion of green skills into a competence-based TVET.

The presentation is based on the results of several research projects that were focused on different aspects of identifying, developing and including green skills in TVET to support transition to greener economies. As research in developing Asian countries demonstrates, although inclusion of new green competencies both generic and specific into curriculum has been observed, it is not enough on its own. There is a need for a holistic framework for greening TVET that includes development of values and attitudes (Pavlova, in press). While industry is slow in re-orienting itself towards greening, government is playing a crucial role in (i) adjusting TVET towards the needs of economy (both current and future), individuals and societies, and (ii) supporting green innovation development and diffusion for stimulating market demand in green skills that is particularly important for curriculum development in a competence-based TVET.

Published: 4 December 2014

\section{References}

1. ADB: Education and skills: Strategies for accelerated development in Asia and the Pacific. Manila, Philippines: ADB; 2009.

2. CPSC: A study of the challenges of TVET in the CPSC member countries. Colombo Plan Staff College for Technician Education. Manila, Philippines: CPSC; 2010.

3. Schwab K: The Global Competitiveness report 2012-2013. Geneva: World Economic Forum; 2012.

4. The European Commission: EUROPE 2020: A strategy for smart, sustainable and inclusive growth [Internet]., c-2010[cited 2014 September 5]. Available from http://ec.europa.eu/eu2020/pdf/COMPLET\%20EN\% 20BARROSO\%20\%20\%20007\%20-\%20Europe\%202020\%20-\%20EN\% 20version.pdf.

5. The Central People's Government of the People's Republic of China: The 12th Five-Year Plan for economic and social development of China (2011- 2015) [Internet]., c-2011[cited 2014 September 5]. Available form http://www.gov.cn/2011lh/content_1825838.htm.

6. United Nation: Economic and Social Survey of Asia and Pacific (ESCAP): 2013 Year-end update [Internet]., c-2013[cited 2014 September 5]. Available from http://www.unescap.org/sites/default/files/yearendupdate2013.pdf.

7. United Nation: Economic and Social Survey of Asia and Pacific (ESCAP): Pursuing Shared Prosperity in an era of turbulence and high commodity prices [Internet]., c-2012[cited 2014 September 5]. Available from http:// www.unescap.org/pdd/publications/survey2012/download/Survey_2012.pdf.

8. Hong Kong's Information Services Department: Gov't keen to nurture green industry [Internet]., c-2013[cited 2014 September 5]. Available from http://www.news.gov.hk/en/record/html/2013/12/20131204_125609.shtml.

9. Pavlova M: Green skills as the agenda for the competence-movement in TVET. In Competence-based Vocational and Professional Education. Springer; M Mulder and J. Winterton .

doi:10.1186/2193-1801-3-S1-K3

Cite this article as: Pavlova: TVET as an important factor in country's economic development. SpringerPlus 2014 3(Suppl 1):K3.

\section{Submit your manuscript to a SpringerOpen ${ }^{\circ}$ journal and benefit from:}

- Convenient online submission

- Rigorous peer review

- Immediate publication on acceptance

- Open access: articles freely available online

- High visibility within the field

- Retaining the copyright to your article

Submit your next manuscript at $>$ springeropen.com 